\title{
PENGARUH STRATEGI PEMBELAJARAN DAN EFIKASI DIRI TERHADAP HASIL BELAJAR MENGOLAH MAKANAN KONTINENTAL PROGRAM STUDI TATA BOGA
}

\author{
Elfrida Nababan', Julaga Situmorang ${ }^{2}$, Abdul Muin Sibuea ${ }^{3}$ \\ ${ }^{1}$ Sekolah Menengah Kejuruan Negeri 10 Kota Madya Medan, \\ ${ }^{2,3}$ Pascasarjana Universitas Negeri Medan \\ elfrida_nababan@gmail.com
}

\begin{abstract}
Abstrak: Penelitian ini bertujuan untuk: (1) mengetahui hasil belajar mengolah makanan kontinental antara siswa yang diajar dengan menggunakan strategi pembelajaran latihan lebih tinggi lebih unggul dari pada menggunakan strategi demonstrasi, (2) Mengetahui keunggulan hasil belajar mengolah makanan kontinental antara siswa yang memiliki efikasi diri tinggi lebih unggul dari pada yang memiliki efikasi diri rendah, dan (3) Mengetahui interaksi antara strategi pembelajaran dan efikasi diri siswa dalam memberikan pengaruh terhadap hasil belajar mengolah makanan kontinental. Populasi penelitian ini adalah seluruh siswa kelas XI Tata Boga, sampel sebanyak 64. Metode eksperimental semu. Uji hipotesis dengan analisis varians (ANAVA), dan uji lanjut dengan uji-Tuckey. Hasil penelitian menunjukkan: (1). Hasil belajar mengolah makanan kontinental yang diajar dengan strategi latihan lebih tinggi dari pada yang diajar dengan strategi demonstrasi, (2) Hasil belajar mengolah makanan kontinental yang memiliki efikasi diri tinggi lebih tinggi dari yang memiliki efikasi diri rendah rendah, dan (3). Terdapat interaksi antara strategi mengajar latihan dan efikasi diri tinggi terhadap hasil belajar mengolah makanan kontinental lebih tinggi dari pada strategi mengajar demonstrasi dengan efikasi diri rendah. Hasil analisis data menunjukkan bahwa siswa yang memiliki efikasi diri tinggi lebih efektif di ajar dengan menggunakan strategi latihan, sedangkan siswa yang mempunyai efikasi diri rendah, lebih efektif diajar dengan menggunakan strategi demonstrasi.
\end{abstract}

Kata Kunci: strategi pembelajaran, latihan, demonstrasi, efikasi diri, mengolah makanan kontinental, tata boga

\begin{abstract}
This study aims to: (1) find out the results of learning to process continental food between students who are taught using a learning strategy of higher training is superior than using a demonstration strategy, (2) Knowing the advantages of learning outcomes in processing continental food among students who have efficacy high self is superior than those who have low self-efficacy, and (3) Knowing the interaction between learning strategies and student self-efficacy in influencing learning outcomes in processing continental food. The population of this study was all students of class XI Catering, a sample of 64. Quasi-experimental methods. Hypothesis testing with analysis of variance (ANAVA), and further testing with the Tuckey-test. The results showed: (1). The results of learning to process continental food taught with training strategies are higher than those taught with demonstration strategies, (2) The learning outcomes of processing continental food that have high self-efficacy are higher than those having low self-efficacy, and (3). There is an interaction between the strategy of teaching exercise and high self-efficacy towards learning outcomes in processing continental food is higher than the teaching strategy of demonstration with low self-efficacy. The results of data analysis show that students who have high self-efficacy are more effectively taught by using a strategy of training, while students who have low self-efficacy are more effectively taught by using a demonstration strategy.
\end{abstract}

Keywords: learning strategies, exercises, demonstrations, self-efficacy, processing continental food, catering

\section{PENDAHULUAN}

Mutu pendidikan yang masih rendah salah satu penyebabnya adalah lemahnya proses pembelajaran. Dalam proses pembelajaran, anak kurang didorong untuk mengembangkan kemampuan berpikir. Proses pembelajaran di dalam kelas diarahkan kepada kemampuan anak untuk menghafal informasi, otak anak dipaksa untuk mengingat dan menimbun berbagai informasi tanpa dituntut untuk memahami informasi yang diingatnya itu untuk menghubungkannya dengan kehidupan sehari hari.Akibatnya anak didik pintar secara teoritis dan miskin secara aplikasi, menurut Sanjaya (2006:51).

Salah satu penyebab permasalahan pendidikan adalah masih rendahnya kualitas guru yang berimplikasi terhadap proses pembelajaran, dimana guru kurang dapat mendorong pengembangan kemampuan 
berpikir, masih diarahkan kemampuan menghafal informasi, otak anak dipaksa untuk mengingat dan menimbun berbagai informasi tanpa dituntut untuk memahami informasi yang diingatnya dan menghubungkannya dengan kehidupan sehari-hari. SMK. Guru tata boga kurang mampu dalam melaksanakan profesinya secara kompeten. Mereka belum berhasil melaksanakan tanggung jawabnya untuk mendidik siswa secara sistematik melalui pengolahan makanan kontinental.

Guru masih jarang memakai strategi mengajar demonstrasi dan latihan. Sabri (2010:57) mengemukakan bahwa demonstrasi adalah suatu strategi mengajar yang memperlihatkan bagaimana proses terjadinya sesuatu. Ini dapat dilakukan oleh guru atau orang lain yang sengaja diminta melakukan dalam suatu proses. Sedangkan strategi latihan menurut Sabri umumnya digunakan untuk memperoleh suatu ketangkasan atau keterampilan dari apa yang telah dipelajari. Hal inilah yang membuat peneliti tertarik untuk membantu guru dan siswa agar mampu meningkatkan kemampuannya dalam mengolah makanan kontinental, Sehingga hasil belajar siswa dapat tercapai. Diharapkan dengan strategi mengajar guru yang bervariasi dengan memakai strategi demonstrasi dan latihan siswa lebih tertarik untuk belajar mengolah makanan kontinental.

\section{Hakikat Hasil Belajar Mengolah Makanan Kontinental}

Belajar adalah kegiatan yang berproses dan merupakan unsur yang sangat fundamental dalam penyelenggaraan setiap jenis dan jenjang pendidikan. Sabri (2010:19) mengemukakan belajar adalah proses perubahan perilaku berkat pengalaman dan pelatihan. Selanjutnya Seels \& Richey (1994:12) menyebutkan bahwa belajar menyangkut adanya perubahan yang relatif permanen pada pengetahuan atau perilaku seseorang karena pengalaman. Hal ini dapat diartikan belajar ialah perubahan tingkah laku, baik yang menyangkut pengetahuan, keterampilan, sikap, bahkan meliputi segenap aspek pribadi. Perubahan tersebut bersifat (a) intensional, yaitu perubahan yang terjadi karena pengalaman atau praktek yang dilakukan, proses belajar dengan sengaja dan disadari, bukan terjadi secara kebetulan, (b) positif, yaitu perubahan yang bermanfaat sesuai dengan harapan pelajar, disamping menghasilkan sesuatu yang baru dan lebih baik dibandingkan sebelumnya, (c) aktif, yaitu perubahan yang terjadi karena usaha yang dilakukan pelajar, bukan terjadi sendirinya, (d) efektif, yaitu perubahan yang memberikan pengaruh dan manfaat bagi pelajar, dan (e) fungsional, yaitu perubahan yang relatif tetap serta dapat diproduksi atau dimanfaatkan setiap kali dibutuhkan.

Lebih lanjut Mel Silberman (2009:6) menjelaskan bahwa belajar yang sesungguhnya tidak terjadi, tanpa ada kesempatan untuk berdiskusi, membuat pertanyaan, mempraktikkan bahkan mengajarkan kepada orang lain. Untuk itu belajar memerlukan beberapa usaha mengekspose materi agar lebih mudah untuk mencerna dan memahamimya, dimana setiap cara untuk persentase memiliki konsep dalam pemahaman peserta didik.

Gagne \& Briggs (1979:125) mengemukakan bahwa hasil belajar dapat dikelompokkan ke dalam lima kategori, yaitu keterampilan intelektual, strategi kognitif, informasi verbal, kemampuan motorik dan sikap. Romizowski (1981:231) menyatakan, "hasil belajar diperoleh dalam bentuk pengetahuan dan keterampilan”. Pengetahuan dikelompokkan kepada empat kategori, yaitu fakta, konsep, prosedur dan prinsip. Sedangkan menurut Dimyati (2006:78) hasil belajar dibagi dalam tiga kawasan yaitu; kognitif, afektif dan psikomotorik. Kawasan kognitif terdiri dari pengetahuan, pemahaman, penerapan, analisis, sintesi, dan evaluasi. Kawasan afektif terdiri dari; penerimaan, partisipasi, penilaian, penentuan sikap, organisasi, dan pembentukan pola hidup. Kawasan psikomotorik yaitu; persepsi, kesiapan, gerakan terbimbing, gerakan yang terbiasa, gerakan kompleks, penyesuai gerak, dan kreativitas.

Sementara hasil belajar yang dicapai siswa dipengaruhi oleh dua faktor utama, yakni faktor dari lingkungan dan faktor yang datang dari diri siswa terutama kemampuan yang dimilikinya. Faktor kemampuan siswa besar sekali pengaruhnya terhadap hasil belajar siswa di sekolah seperti yang dikemukakan oleh Clark (dalam Sabri, 2010:45) bahwa hasil belajar siswa di sekolah 70 persen dipengaruhi oleh kemampuan siswa dan 30 persen dipengaruhi oleh lingkungan. Di samping faktor kemampuan yang dimiliki siswa, juga ada faktor lain, seperti motivasi belajar, minat dan perhatian, sikap dan kebiasaan belajar, ketekunan, sosial, ekonomi, dan factor fisik dan psikis. Sedangkan menurut Caroll (dalam Sabri, 
2010:46) berpendapat bahwa hasil belajar siswa dipengaruhi oleh lima faktor, yakni; 1) bakat pelajar; (2) waktu yang tersedia untuk belajar; (3) waktu yang diperlukan siswa untuk menjelaskan pelajaran; (4) kualitas pengajaran; dan (5) kemampuan individu.

Menurut Saetler (dalam Miarso 2007:111) bahwa teknologi pembelajaran adalah rumusan yang mempunyai prinsipprinsip (1) aktivitas diri; (2) minat/motivasi; (3) kesiapan mental; (4) individualisasi; dan (5) sosialisasi. Selanjutnya Miarso (2007:111) menjelaskan untuk melaksanakan prinsipprinsip ini seorang guru harus mengendalikan kegiatan belajar anak di dalam kelas ke arah yang dikehendaki, namun dengan tetap memperhatikan minat dan respon anak terhadap stimulasi yang diberikan.

Cahyanan (2009) mengemukakan makanan kontinental adalah makanan yang dihidangkan secara bergilir dari makanan pembuka sampai makanan penutup. Selanjutnya menurut Olive (2003) menyatakan bahwa makanan kontinental adalah makanan Eropa yang dihidangkan secara bergilir mulai dari makanan pembuka sampai dengan makanan penutup atau sering juga disebut makanan barat.

Berkaitan dengan hasil belajar, maka hasil belajar mengolah makanan kontinental merupakan gambaran dan tingkat kesanggupan berakting, yang oleh Romizowski (1981) diperoleh dalam bentuk pengetahuan dan keterampilan. Dalam bentuk pengetahuan meliputi fakta, konsep, prosedur dan prinsip. Konsep. prosedur dan prinsip dalam materi mengolah makanan kontinental akan berarti bagi siswa apabila dihubungkan dengan fakta yang ada dalam kehidupan sehari-hari siswa. Sedangkan bentuk kemampuan yang menggambarkan tingkat kesanggupan berakting, yaitu kemampuan yang berkaitan dengan keterampilan seperti mengolah makanan kontinental.

\section{Hakikat Strategi Pembelajaran}

Syah (2010:211) mendefinisikan strategi mengajar (teaching strategy) sebagai sejumlah langkah yang direkayasa sedemikian rupa untuk mencapai tujuan pengajaran tertentu. Sebuah strategi mengajar dapat berlaku umum bagi semua guru bidang studi selama orientasi sasarannya sama. Oleh karena itu, seorang guru dituntut memiliki kemampuan mengatur secara umum komponen-komponen pembelajaran, sehingga terjalin keterkaitan fungsi antar komponen pembelajaran dimaksud. Strategi berarti pilihan pola kegiatan belajar mengajar yang diambil untuk mencapai tujuan secara efektif.

Menurut Knik dan Gustafson (dalam Sagala,2007:64) dikemukakan bahwa pembelajaran merupakan suatu proses yang sistematis melalui tahap rancangan, pelaksanaan, dan evaluasi. Artinya bahwa pembelajaran itu tidak terjadi seketika, tetapi sudah dirancang secara menyuluruh dalam satuan pembelajaran dan dilaksanakan melalui tahap pembelajaran. Hamalik (2004:89) menambahkan bahwa strategi pembelajaran adalah sebagai sistim menyeluruh yang terdiri dari sejumlah komponen yaitu komponen masukan atau input, komponen proses dan komponen produk atau out-put.

Dalam memilih strategi pembelajaran perlu dibuat pertimbangan-pertimbangan. Menurut Miarso (2007:532) ada 7 pertimbangan dalam pemimilhan strategi pembelajaran yaitu (1) Tujuan belajar: jenis dan jenjangnya; (2) isi ajaran: sifat, kedalaman, dan banyaknya; (3) pembelajar: latar belakang, motivasi, serta kondisi pisik dan mental; (4) tenaga kependidikan: jumlah, kualifikasi, dan kompetensinya; (5) waktu: lama dan jadwalnya; (6) sarana yang dapat dimanfaatkan; dan (7) biaya. Selanjutnya Gagne (1987:177) menyebutkan Pengetahuan tentang instruksi atau perintah dalam membuat tugas mempunyai dua unsur-unsur, yaitu (a) komponen strategi apa yanga kita gunakan dan (b) belajar situasi (artinya kapan sebaiknya kita menggunakan masing-masing komponen strategi itu). Selanjutnya Seels dan Rechey (1994:80) juga mengemukakan dalam memilih strategi pembelajaran dimulai dengan mengklasifikasikan tugas belajar, bagimanapun fase-fase lain dalam proses perancangan juga tergantung dari hakekat tugas belajar termasuk teknik-teknik untuk memberikan umpan balik.

Newman dan Logan sebagaimana dikuti Abu Ahmadi (dalam Sabri 2010:2) mengemukakan bahwa strategi meliputi empat masalah, yaitu: (1) mengidentifikasikan serta menetapkan spesifikasi dan kualifikasi perubahan tingkah laku dan kepribadian peserta didik sesuai dengan tujuan yang diharapkan, (2) memilih sistem pendekatan belajar mengajar berdasarkan aspirasi dan pandangan hidup masyarakat, (3) memilih dan menetapkan prosedur, metode, dan teknik pembelajaran yang dianggap paling tepat dan efektif sehingga 
dapat dijadikan pegangan dalam kegiatan pembelajaran, dan (4) menetapkan normanorma dan batas minimal keberhasilan atau kriteria dan standar keberhasilan sehingga dapat dijadikan pedoman guru dalam melakukan evaluasi hasil kegiatan pembelajaran.

Selanjutnya menurut Dick \& Carey (2005:213) hal yang diperlukan untuk mengembangkan suatu strategi didesain mulai dari hal kecil yang meliputi: (1) tujuan instruksional dan tujuan analisis; ( 2) identifikasi pengetahuan, ( 3) daftar sasaran hasil capaian, ( 4) materi test yang berhubungan, ( 5) menganalisa siswa, ( 6) analisa materi pelajaran, dan ( 7) analisa konteks capaian atau tujuan. Hal senada juga dikemukakan oleh Uno (2011: 155) bahwa dalam strategi pembelajaran harus memuat Sembilan urutan kegiatan yang dilakukan yaitu: (1) memberikan motivasi, (2) menjelaskan tujuan, (3) mengingatkan kompetensi prasyarat, (4) memberikan stimulus, (5) memberikan petunjuk belajar, (6) menimbulkan penampilan, (7) memberikan umpan balik, (8) menilai penampilan, dan (9) mentimpulkan

$$
\text { Dalam melaksanakan strategi }
$$

pembelajaran perlu diketahui prinsip-prinsip penggunaan strategi pembelajaran itu. Prinsip yang dimaksud adalah hal yang perlu diperhatikan dalam menggunakan atau memilih strategi pembelajaran. Secara umum bahwa tidak semua penggunaan strategi pembelajaran cocok digunakan untuk mencapai semua tujuan. Setiap strategi memiliki kekhasan sendirisendiri. Oleh sebab itu, guru perlu memahami prinsip-prinsip penggunaan strategi pembelajaran. Menurut Sanjaya (2006:129) ada empat prinsip yang harus dipahami guru dalam penggunaan strategi pembelajaran yaitu: (1) berorientasi pada tujuan dimana tujuan pembelajaran dapat menentukan suatu strategi yang harus digunakan guru; (2) berorientasi pada aktivitas dimana strategi pembelajaran harus dapat mendorong aktivitas siswa baik pisik maupun mental; (3) berorientasi pada individualitas, walaupun kita mengajar pada sekelompok siswa, namun pada hakikatnya yang ingin kita capai adalah perubahan perilaku setiap individu; dan (4) berorientasi pada integritas, strategi pembelajaran harus dapat mengembangkan seluruh aspek kepribadian siswa secara terintegrasi.

\section{Hakikat Strategi Pembelajaran Latihan}

Strategi latihan pada umumnya digunakan untuk memperoleh suatu ketangkasan atau keterampilan dari apa yang telah dipelajari. Sabri (2010:60) mengemukakan prinsip dan petunjuk menggunakan strategi latihan adalah sebagai berikut: (1) siswa harus diberi pengertian yang mendalam sebelum diadakan latihan tertentu; (2) latihan untuk pertama kali hendaknya bersifat diagnosis, mula-mula kurang berhasil, lalu diadakan perbaikan untuk kemudian bisa lebih sempurna; (3) harus disesuaikan dengan taraf kemampuan siswa; dan (4) proses latihan hendaknya mendahulukan hal-hal yang esensial dan berguna.

Mengingat strategi latihan dapat mengembangkan bakat atau inisiatif siswa untuk berpikir, maka hendaknya latihan disiapkan untuk mengembangkan kemampuan motorik yang sebelumnya dilakukan diagnosis agar kegiatan itu bermanfaat bagi pengembangan motorik siswa. Menurut Guthrie (dalam Lutan, 1998:23) bahwa keterampilan dapat diperoleh melalui pengulangan. Drill dapat berguna untuk memperlancar siswa dalam melakukan lebih banyak respon yang tepat dan benar. Penguasaan suatu keterampilan atau pemantapan keterampilan baru akan diperoleh melalui repetisi dimana setiap fase latihan mengembangkan kekompakan keterkaitan stimulus-respon.

\section{Hakikat Strategi Pembelajaran Demonstrasi}

Menurut Sanjaya (2007:150) strategi demonstrasi adalah strategi pembelajaran dengan memperagakan dan mempertunjukkan kepada siswa tentang suatu proses, situasi atau benda tertentu. Selanjutnya dikatakan dalam strategi demonstrasi tidak akan terjadi verbalisme, karena siswa disuruh langsung memperhatikan bahan pelajaran yang dijelaskan. Dengan demikian proses pembelajaran akan lebih menarik sebab siswa tak hanya mendengar, tetapi juga melihat peristiwa yang terjadi. Hal ini akan memberikan kesempatan kepada siswa untuk membandingkan antara teori dan kenyataan yang akhirnya menambah keyakinan siswa terhadap kebenaran materi pembelajaran.

Tujuan pokok penggunaan strategi demonstrasi dalam proses belajar mengajar ialah untuk memperjelas pengertian konsep dan memperlihatkan (meneladani) cara melakukan sesuatu atau proses terjadinya sesuatu. Ada 
asumsi psikologis yang melatarbelakangi perlunya penggunaan strategi demonstrasi dalam proses belajar mengajar, yakni belajar adalah proses melakukan dan mengalami sendiri (learning by doing and experiencing) apa-apa yang dipelajar. Dengan melakukan dan mengalami sendiri, siswa diharapkan dapat menyerap kesan yang mendalam ke dalam benaknya. Sementara stategi demonstrasi menurut Sabri (2010:57) dapat dilakukan apabila: (1) anak mempunyai keterampilan tertentu; (2) untuk memudahkan berbagai penjelasan; (3) untuk membantu anak memahami dengan jelas jalannya suatu proses dengan penuh perhatian; dan (4) untuk menghindari verbalisme.

Menurut Sudjana (2001:154) teknik demonstrasi dalam pelaksanaannya dibagi dua yaitu teknik demonstrasi proses dan teknik demonstrasi hasil. Teknik demonstrasi proses digunakan untuk menunjukkan atau memperagakan suatu proses atau rangkaian langkah-langkah kegitan. Sedangkan teknik demonstrasi hasil diperagakan menjadi bahan utama dalam kegiatan pembelajaran. Bahan belajar tidak hanya ditunjukkan oleh pendidik tetapi juga oleh peserta didik yang berperan aktif dalam melakukan proses sampai sejauh mana hasilnya.

Selanjutnya Darajat (dalam Syah, 2010:206) berpendapat banyak keuntungan psikologis pedagogis yang dapat diraih dengan menggunakan strategi demontrasi, antara lain: (1) perhatian siswa dapat lebih dipusatkan; (2) proses belajar siswa lebih terarah pada materi yang sedang dipelajari; dan (3) pengalaman dan kesan sebagai hasil pembelajaran lebih melekat dalam diri siswa.

Tujuan pengajaran menggunakan strategi demonstarasi adalah untuk memperlihatkan proses terjadinya suatu peristiwa sesuai materi ajar, cara pencapaiannya, dan kemudahan untuk memahami oleh siswa dalam pengajaran. Menurut Sagala (2003:211) strategi demonstrasi mempunyai kebaikan-kebaikan, antara lain: (1) perhatian murid dapat dipusatkan kepada halhal yang dianggap penting oleh guru sehingga hal penting itu dapat diamati secara teliti; (2) dapat membimbing peserta didik kearah berpikir yang sama dalam satu saluran pikiran yang sama; (3) ekonomis dalam jam pelajaran di sekolah dan ekonomis dalam waktu yang panjang dapat diperlihatkan melalui demonstrasi dengan waktu yang pendek; (4) dapat mengurangi kesalahan-kesalahan bila dibandingkan dengan hanya membaca atau mendengarkan, karena murid mendapatkan gambaran yang jelas dari hasil pengamatannya; (5) karena gerakan dan proses dipertunjukkan maka tidak memerlukan keterangan-keterangan yang banyak; dan (6) beberapa persoalan yang menimbulkan pertanyaan atau keraguan dapat diperjelas waktu proses demonstrasi.

Strategi demonstrasi biasanya diaplikasikan dengan menggunakan alat-alat bantu pengajaran seperti benda-benda miniature, gambar, perangkat alat-alat laboratorium, dan lain-lain. Syah (2010:207) menjelaskan tentang kelemahan-kelemahan metode demonstrasi, yakni: (1) mahalnya biaya yang harus dikeluarkan terutama untuk pengadaan alat-alat modern; (2) demonstrasi tak dapat dilakukan/diikuti dengan baik oleh siswa yang memiliki cacat tubuh atau kelainan/kekurangmampuan fisik tertentu; dan (3) tidak semua hal dapat didemonstarsikan didepan kelas.

\section{Hakikat Efikasi Diri}

Efikasi diri (self-efficacy) yang diperkenalkan oleh Bandura (1991 :213) merupakan kemampuan yang dirasakan individu untuk mengatasi situasi khusus sehubungan dengan penilaian atas kemampuan untuk melakukan satu tindakan yang ada hubungannya dengan tugas khusus atau situasi tertentu. Efikasi diri ini bersumber dari teori belajar sosial, yaitu menekankan hubungan kasual timbal balik antara faktor lingkungan dengan faktor personal yang saling berkaitan. Defenisi formal efikasi diri yang biasanya digunakan pernyataan Bandura (1982:122) mengenai penilaian (jugment) atau keyakinan pribadi tentang seberapa baik seseorang dapat melakukan tindakan yang diperlukan untuk berhubungan dengan situasi prosfektif. Defenisi yang lebih luas dan lebih tepat untuk perilaku organisasi positif diberikan Luthans dan Stajkovic (2006:338), bahwa efikasi diri mengacu pada keyakinan individu (confidensi) mengenai kemampuannya untuk memobilisasi motivasi, sumber daya kognitif, dan tindakan yang diperlukan agar berhasil melaksanakan tugas dalam konteks tertentu. Sedangkan Baron \& Greenberg (1990:89), menyatakan efikasi diri adalah suatu kenyataan seseorang mengenai kemampuannya untuk melakukan tugas-tugas tertentu yang spesifik. Lebih lanjut Bryrner (1993:162), mengemukakan efikasi diri merupakan konsep 
diri dan berkaitan dengan persepsi seseorang terhadap kemampuan dan keahlian dalam menghadapi suatu tugas tertentu.

Penilaian efikasi diri merupakan proses penarikan kesimpulan yang mempertimbangkan sumbangan faktor kemampuan dan bukan kemampuan pada keberhasilan dan kegagalan pada performansi. Sejauh mana individu mengubah efikasinya melalui pengalaman performansi, akan tergantung pada faktor-faktor lain seperti kesulitan tugas, besar usaha yang dikeluarkan, besar bantuan eksternal yang diterima, situasi pada saat performansi dan pola-pola keberhasilan dan kegagalan (Bandura,1981:113). Dapat dikatakan bahwa Efikasi tergantung pada kemampuan individu. Oleh karena itu pada umunya individu yang berkemampuan tinggi memiliki efikasi yang lebih tinggi tentang belajar dibandingkan dengan individu yang berkemampuan rendah.

Ada beberapa hal yang dapat mempengaruhi efikasi diri seseorang. Menurut Bandura (1981:187) faktor-faktor yang mempengaruhi proses pembentukan efikasi diri seseorang antara lain: (1). Pencapaian secara aktif; (2). Pengalaman tidak langsung; (3). Persuasi verbal; dan (4). Keadaan fisiologis. Demikian juga dengan siswa dalam mengikuti pembelajaran. siswa harus memiliki keyakinan bahwa pembelajaran yang berkualitas dapat dicapai, bahwa kinerja akan semakin baik.

Luthans (2006:340) mengemukakan bahwa efikasi diri juga memainkan peranan vital dalam menentukan kinerja manusia lainnya seperti aspirasi tujuan, intensif hasil, dan kesempatan yang dirasakan terhadap suatu proyek. Apapun tingkat tujuan yang dipilih, seberapa banyak usaha yang dikeluarkan untuk mencapai tujuan tertentu, dan bagaimana reaksi/ketahanan seseorang saat menghadapi masalah dalam proses pencapaian tujuan sangat dipengaruhi oleh efikasi diri. Begitu pula dengan intensif hasil yang diantisipasi seseorang. Orang dengan efikasi diri tinggi mengharapkan keberhasilan dan mendapat yang diinginkan. Dan intensif hasil yang positif, sementara orang dengan efikasi rendah mengharapkan kegagalan dan memikirkan disintensif hasil yang negatif.

Rumusan masalah yang akan ditelusuri dalam penelitian ini adalah sebagai berikut: (1) Apakah siswa yang diajar dengan strategi pembelajaran latihan memperoleh hasil belajar mengolah makanan kontinental lebih tinggi dibandingkan dengan kelompok siswa yang diajar dengan strategi pembelajaran demonstrasi?; (2) Apakah siswa yang memiliki efikasi diri tinggi memperoleh hasil belajar mengolah makanan kontinental lebih tinggi dibandingkan dengan kelompok siswa yang memiliki efikasi rendah?; dan (3) Apakah terdapat interaksi antara strategi pembelajaran dan efikasi diri siswa terhadap hasil belajar mengolah makanan kontinental?

\section{METODE}

Populasi penelitian ini adalah seluruh siswa kelas XI Tata Boga yang terdiri 2 kelas, yaitu kelas XI Boga 1 berjumlah 32 orang dan Boga 2 berjumlah 32 orang. Sehingga total populasi seluruhnya adalah 64 orang. Dalam hal ini seluruh populasi diambil jadi sampel penelitian. Satu kelompok kelas eksperimen dikenai pembelajaran dengan strategi latihan dan satu kelas eksperimen lainnya dikenai strategi demonstrasi. Teknik yang dipergunakan dalam penentuan kelas eksperimen adalah pengambilan sampel secara acak (cluster random sampling) dan ditentukan secara random sederhana dengan teknik undian, dengan demikian ada 64 orang sebagai sampel dalam penelitian ini.

Sebelum dilakukan penelitian, kedua kelas sampel terlebih dahulu diberikan tes efikasi diri untuk mengukur tingkat efikasi diri siswa. Dari hasil perolehan skor masingmasing siswa dibuat peringkat hasil skor efikasi diri siswa. Selanjutnya dari tiap-tiap kelas sampel ini ditetapkan kelompok siswa yang memiliki efikasi diri tinggi dan kelompok siswa yang memiliki efikasi rendah, sesuai dengan kriteria yang berlaku.

Penelitian ini menggunakan metode quasi eksperiment (eksperimen semu). Metode ini dipilih karena kelas yang digunakan untuk perlakuan merupakan kelas yang sudah terbentuk sebelumya. Pada eksperiman, peneliti mengubah strategi pembelajaran konvensional dengan menggunakan strategi pembelajaran latihan dan strategi demonstrasi dan dari hasil undian di peroleh bahwa kelas XI Boga 1 menggunakan strategi latihan dan kelas XI boga 2 menggunakan strategi demonstrasi. Metode ini dipakai untuk membandingkan mana yang lebih baik antara strategi pembelajaran demonstrasi dan strategi pembelajaran latihan digunakan pada siswa yang memiliki efikasi diri tinggi dan siswa yang memiliki efikasi diri rendah. Kemudian metode ini dipakai karena semua variabel tidak dapat 
dikontrol dan kelas telah terbentuk sebelumnya. Adapun variabel bebas (variabel eksperimen) yang menjadi ruang lingkup penelitian: (1) strategi pembelajaran demonstrasi (2) strategi pembelajaran latihan. Kemudian satu variabel terikat (tercoba) yaitu hasil pembelajaran mengolah makanan kontinental pada bahan pembelajaran program Sekolah Menengah
Kejuruan Program Studi Tata Boga. Sedangkan sebagai variabel moderator adalah efikasi diri, yang terdiri dari efikasi diri tinggi dan efikasi diri rendah. Variabel-variabel tersebut selanjutnya dimasukkan dalam desain penelitian. Adapun desain penelitian yang digunakan seperti pada Tabel 3.1 di bawah ini:

Tabel 3.1 Rancangan Eksperimen Desain Faktorial 2 × 2

\begin{tabular}{|c|c|c|}
\hline $\begin{array}{c}\text { Strategi pembelajaran } \\
\text { Efikasi Diri (B) }\end{array}$ & Latihan (A1) & Demonstrasi (A2) \\
\hline Tinggi (B1) & A1B1 & A2B1 \\
\hline Rendah (B2) & A1B2 & A2B2 \\
\hline
\end{tabular}

\section{Keterangan :}

A $\quad=$ Strategi Pembelajaran

B $=$ Efikasi Diri Siswa

A1 = Strategi Pembelajaran Latihan

A2 = Strategi Pembelajaran Demonstrasi

B1 = Kelompok siswa memiliki efikasi diri tinggi

B2 = Kelompok siswa memiliki efikasi diri rendah

A1B1 = Hasil belajar kelompok siswa efikasi diri tinggi dengan perlakuan

strategi pembelajaran Latihan

A2B1 = Hasil belajar kelompok siswa efikasi diri tinggi dengan perlakuan strategi pembelajaran Demonstrasi

A1B2 = Hasil belajar kelompok siswa efikasi diri rendah dengan perlakuan strategi pembelajaran Latihan.

A2B2 = Hasil belajar kelompok siswa efikasi diri rendah dengan perlakuan strategi pembelajaran Demonstrasi.

\section{Teknik Analisis Data}

Teknik analisis data yang digunakan adalah teknik statistik deskriptif dan inferensial. Teknik statistik deskriptif digunakan untuk mendeskripsikan data antara lain : nilai rata-rata (mean), standard deviasi, median, dan modus, kemudian disusun dalam daftar distribusi frekuensi serta dalam bentuk bagan. Teknik statistik inferensial digunakan untuk menguji hipotesis penelitian, dimana teknik inferensial yang digunakan adalah teknik analisis varians Anava 2 jalur (desain faktorial 2 x 2 dengan taraf signifikansi 0.05. Sebelum Anava 2 jalur dilakukan terlebih dahulu ditentukan prasyarat normalitas akan menggunakan Uji Liliefors, sedangkan untuk uji persyaratan homogenitas akan menggunakan uji F dan uji Barlet. Apabila uji Anava 2 jalur ternyata signifikan, dan ada interaksi antara strategi mengajar dengan efikasi diri maka diadakan uji lanjut.

Adapun hipotesis yang diuji dalam penelitian ini adalah sebagai berikut :

Pertama $\quad \mathrm{H} 0: \mu \mathrm{A} 1=\mu \mathrm{A} 2$

Kedua $\quad$ Ha: $\mu \mathrm{A} 1>\mu \mathrm{A} 2$

Ha: $\mu \mathrm{B} 1>\mu \mathrm{B} 2$

Ketiga $\quad \mathrm{H} 0: \mathrm{Mm}><\mathrm{Ed}=0$

$\mathrm{Ha}: \mathrm{Mm}><\mathrm{Ed} \neq 0$

Dengan:

H0 : Hipotesis Nol

$\mathrm{Ha}$ : Hipotesis Alternatif

$\mathrm{A} 1$ : Rata-rata hasil belajar pengolahan makanan kontinental dengan perlakuan strategi pembelajaran latihan

$\mu$ A2 : Rata-rata hasil belajar pengolahan makanan kontinental dengan perlakuan strategi pembelajaran demonstrasi

$\mathrm{B} 1$ : Rata-rata hasil belajar pengolahan makanan kontinental siswa efikasi diri tinggi

$\mu$ B2 : Rata-rata hasil belajar pengolahan makanan kontinental siswa efikasi diri rendah

Mm : Strategi pembelajaran

Ed : Efikasi diri

\section{HASIL DAN PEMBAHASAN}

Hasil

Pengujian hipotesis dilakukan dengan menggunakan teknik analisis Varians (ANAVA). Untuk keperluan analisis varians, data-data selengkapnya terdapat pada bagian 
lampiran 21 hal 195. Hasil perhitungan yang diperoleh dirangkum dalam tabel perhitungan

Analisis Varians seperti Tabel 1 dibawah ini:

Tabel 1. Rangkuman Data Hasil Penelitian

\begin{tabular}{|c|c|c|c|c|}
\hline \multicolumn{2}{|c|}{ Variabel } & \multicolumn{2}{|c|}{ Strategi Mengajar } & \multirow{2}{*}{ Total } \\
\cline { 3 - 4 } & \multirow{4}{*}{ Tinggi } & Latihan & Demonstrasi & \\
\hline \multirow{4}{*}{ Evikasi Diri } & $\mathrm{N}=16$ & $\mathrm{~N}=16$ & $\mathrm{~N}=32$ \\
& & $\bar{X}=79,75$ & $\bar{X}=60,50$ & $\bar{X}=70,13$ \\
& & $\sum \mathrm{X}=1.276$ & $\sum \mathrm{X}=968$ & $\sum \mathrm{X}=2.244$ \\
& & $\sum \mathrm{X}^{2}=95.932$ & $\sum \mathrm{X}^{2}=59.058$ & $\sum \mathrm{X}^{2}=154.990$ \\
\cline { 3 - 4 } & \multirow{4}{*}{ Rendah } & $\mathrm{N}=16$ & $\mathrm{~N}=16$ & $\mathrm{~N}=32$ \\
& & $\bar{X}=62,13$ & $\bar{X}=72,50$ & $\bar{X}=67,31$ \\
& & $\sum \mathrm{X}=994$ & $\sum \mathrm{X}=1.160$ & $\sum \mathrm{X}=2.154$ \\
& & $\sum \mathrm{X}^{2}=62.130$ & $\sum \mathrm{X}^{2}=90.428$ & $\sum \mathrm{X}^{2}=152.558$ \\
\hline \multirow{2}{*}{ Total } & $\mathrm{N}=32$ & $\mathrm{~N}=32$ & $\mathrm{~N}=64$ \\
& & $\bar{X}=70,94$ & $\bar{X}=66,50$ & $\bar{X}=68,72$ \\
& & $\sum \mathrm{X}=2.270$ & $\sum \mathrm{X}=2.128$ & $\sum \mathrm{X}=4.398$ \\
& & $\sum \mathrm{X}^{2}=158.062$ & $\sum \mathrm{X}^{2}=149.758$ & $\sum \mathrm{X}^{2}=307.548$ \\
\hline
\end{tabular}

Tabel 2. Hasil Perhitungan ANAVA

\begin{tabular}{|l|c|c|c|c|c|}
\hline Sumber Varians & $\begin{array}{c}\text { Jumlah Kuadrat } \\
(\mathrm{JK})\end{array}$ & $\mathrm{Dk}$ & $\begin{array}{c}\text { Rata-rata Jumlah } \\
\text { Kuadrat (RJK) }\end{array}$ & $\mathrm{F}_{\text {hitung }}$ & $\begin{array}{c}\mathrm{F}_{\text {tabel }} \\
(\alpha=0,05)\end{array}$ \\
\hline Antar Kolom & 315,06 & 1 & 315,06 & 10.98 & 3,82 \\
Antar Baris & 126,56 & 1 & 126,56 & 4,41 & 3,82 \\
Interaksi & $3.130,57$ & 1 & $3.130,57$ & 109,08 & 3,82 \\
\hline Antar Kelompok & $3.572,19$ & 3 & $1.190,73$ & - & - \\
Dalam Kelompok & $1.750,75$ & 61 & 28,70 & - & - \\
\hline \multicolumn{1}{|c|}{ Total } & $6.654,35$ & 64 & - & - & - \\
\hline
\end{tabular}

Untuk menguji apakah hasil belajar mengolah makanan kontinental yang diajar dengan strategi latihan berbeda dari pada hasil belajar mengolah makanan kontinental yang diajar dengan strategi demonstrasi, maka digunakan teknik analisis varians (ANAVA).

Dari hasil perhitungan dengan ANAVA diperoleh bahwa $F_{\text {hitung }}=10,98$ dan $\mathrm{F}_{\text {tabel }}=3,82$ pada taraf signifikansi 0,05 . hal ini berarti bahwa $\mathrm{F}_{\text {hitung }}>\mathrm{F}_{\text {tabel, }}$, menunjukkan bahwa hipotesis nol $\left(\mathrm{H}_{0}\right)$ ditolak dan hipotesisi alternatif $\left(\mathrm{H}_{\mathrm{a}}\right)$ diterima. Dengan demikian bahwa hipotesisi penelitian yang menyatakan hasil belajar mengolah makanan kontinental yang diajar dengan strategi latihan berbeda dengan hasil belajar mengolah makanan kontinental yang diajar dengan strategi demonstrasi teruji kebenarannya. Berdasarkan data yang diperoleh juga menunjukkan bahwa nilai rata-rata hasil belajar mengolah makanan kontinental yang diajar dengan strategi latihan lebih tinggi daripada hasil belajar mengolah makanan kontinental yang diajar dengan strategi demonstrasi.
Perbandingan nilai rata-rata dan pengujian ANAVA yang diperoleh dapat disimpulkan hasil belajar mengolah makanan kontinental yang diajar dengan strategi latihan berbeda dengan hasil belajar mengolah makanan kontinental yang diajar dengan strategi demonstrasi.

Pengujian apakah hasil belajar mengolah makanan kontinental yang memiliki efikasi diri tinggi berbeda dengan hasil belajar mengolah makanan kontinental yang memiliki efikasi diri rendah, juga dilakukan dengan menggunakan teknik analisis varians (ANAVA).

Dari hasil perhitungan dengan ANAVA diperoleh bahwa $F_{\text {hitung }}=4,41$ dan $\mathrm{F}_{\text {tabel }}=3,82$ pada taraf signifikansi 0,05 . hal ini berarti bahwa $F_{\text {hitung }}>F_{\text {tabel }}$, menunjukkan bahwa hipotesis nol $\left(\mathrm{H}_{0}\right)$ ditolak dan hipotesisi alternatif $\left(\mathrm{H}_{\mathrm{a}}\right)$ diterima. Dengan demikian bahwa hipotesis penelitian yang menyatakan hasil belajar mengolah makanan kontinental yang memiliki efikasi diri tinggi berbeda dengan hasil belajar mengolah makanan kontinental yang memiliki efikasi diri rendah 
teruji kebenarannya. Berdasarkan data yang diperoleh juga menunjukkan bahwa nilai ratarata hasil belajar siswa yang memiliki efikasi diri tinggi lebih tinggi daripada hasil belajar siswa yang memiliki efikasi diri rendah.

Perbandingan nilai rata-rata dan pengujian ANAVA yang diperoleh dapat disimpulkan hasil belajar mengolah makanan kontinental yang memiliki efikasi diri tinggi berbeda dengan hasil belajar mengolah makanan kontinental yang memiliki efikasi diri rendah.

Pengujian ada tidaknya interaksi antara strategi dengan efikasi diri dalam mempengaruhi hasil belajar mengolah makanan kontinental juga dilakukan dengan menggunakan teknik analisis varians (ANAVA).
Dari hasil perhitungan dengan ANAVA diperoleh bahwa $\mathrm{F}_{\text {hitung }}=109,08$ dan $\mathrm{F}_{\text {tabel }}=3,82$ pada taraf signifikansi 0,05 . hal ini berarti bahwa $F_{\text {hitung }}>\mathrm{F}_{\text {tabel, }}$ menunjukkan bahwa hipotesis nol $\left(\mathrm{H}_{0}\right)$ ditolak dan hipotesisi alternatif $\left(\mathrm{H}_{\mathrm{a}}\right)$ diterima. Dengan demikian bahwa hipotesis penelitian yang menyatakan terdapat interaksi antara strategi dengan efikasi diri dalam mempengaruhi hasil belajar mengolah makanan kontinental teruji kebenarannya.

Berdasarkan hasil pengujian hipotesis di atas dapat juga dilihat bahwa ada interaksi antara strategi mengajar dengan efikasi diri terhadap hasil belajar mengolah makanan kontinental. Interaksi antara strategi mengajar dengan efikasi diri dapat dilihat pada Gambar 1 di bawah ini:

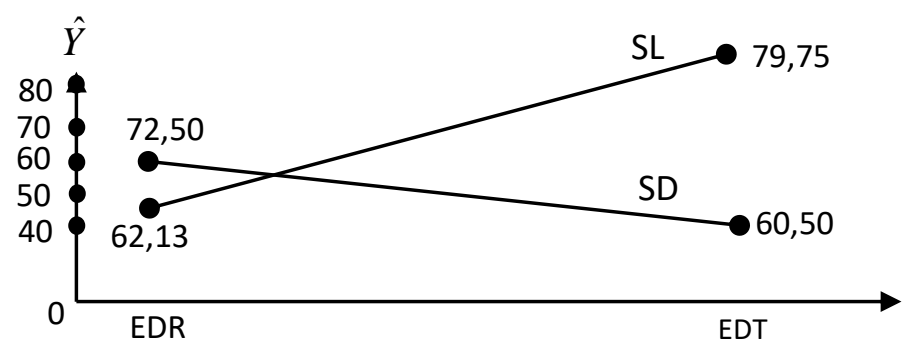

Gambar 1. Grafik Interaksi antara Strategi mengajar dengan Efikasi Diri terhadap Hasil Belajar Mengolah Makanan Kontinental

Keterangan:

$\mathrm{SL} \quad=$ Strategi Latihan

SD $\quad=$ Strategi Demonstrasi

EDT $=$ Efikasi Diri Tinggi

EDR $=$ Efikasi Diri Rendah

Oleh karena adanya interaksi antara strategi mengajar dan efikasi diri dalam mempengaruhi hasil belajar mengolah makanan kontinental serta data yang diperoleh dalam penelitian ini berasal dari sampel yang jumlahnya sama dalam sel ANAVA, maka pelu diadakan uji lanjut dengan menggunakan uji Tuckey. Perhitungan uji lanjut dan hasil selengkapnya seperti pada Tabel 3 berikut ini:

Tabel 3. Ringkasan Hasil Perhitungan Uji Lanjut dengan Uji-Tuckey

\begin{tabular}{|c|c|c|c|}
\hline \multirow{2}{*}{$\begin{array}{c}\text { Nilai kelompok } \\
\text { yang dibandingkan }\end{array}$} & \multirow{2}{*}{$F_{\text {hitung }}$} & $\alpha=0,05$ & $\alpha=0,01$ \\
\cline { 3 - 4 } & 13,29 & 2,15 & 3,00 \\
\hline$\mu_{11}$ dan $\mu_{21}$ & $13,2,00$ & 2,15 & 3,00 \\
\hline$\mu_{11}$ dan $\mu_{12}$ & 1,79 & 2,15 & 3,00 \\
\hline$\mu_{11}$ dan $\mu_{22}$ & 1,29 & 2,15 & 3,00 \\
\hline$\mu_{12}$ dan $\mu_{21}$ & 11,51 & 2,15 & 3,00 \\
\hline$\mu_{22}$ dan $\mu_{21}$ & 10,21 & 2,15 & 3,00 \\
\hline$\mu_{22}$ dan $\mu_{12}$ & & \\
\hline
\end{tabular}

\section{Keterangan:}

$\mu_{11}=$ rata-rata nilai hasil belajar mengolah makanan kontinental yang diajar dengan strategi latihan dan memiliki efikasi diri tinggi.

$\mu_{12}=$ rata-rata nilai hasil belajar mengolah makanan kontinental yang diajar dengan strategi latihan dan memiliki efikasi diri rendah.

$\mu_{21}=$ rata-rata nilai hasil belajar mengolah makanan kontinental yang diajar dengan strategi demonstrasi dan memiliki efikasi diri tinggi. 
$\mu_{22}=$ rata-rata nilai hasil belajar mengolah makanan kontinental yang diajar dengan strategi demonstrasi dan memiliki efikasi diri rendah.

Kriteria penerimaan, jika $F_{\text {hitung }}>F_{\text {tabel }}$ maka ada perbedaan yang signifikan. Dari hasil Uji-Tuckey di atas diperoleh simpulan:

a. Rata-rata nilai hasil mengolah makanan kontinental yang diajar dengan strategi latihan dan memiliki efikasi diri tinggi lebih baik dibandingkan dengan hasil belajar mengolah makanan kontinental yang diajar dengan strategi demonstrasi dan memiliki efikasi diri tinggi.

b. Rata-rata nilai hasil belajar mengolah makanan kontinental yang diajar dengan strategi latihan dan memiliki efikasi diri tinggi lebih baik dibandingkan dengan hasil belajar mengolah makanan kontinental yang diajar dengan strategi latihan dan memiliki efikasi diri rendah.

c. Rata-rata nilai hasil belajar mengolah makanan kontinental yang diajar dengan strategi latihan dan memiliki efikasi diri tinggi tidak lebih baik dibandingkan dengan hasil belajar mengolah makanan kontinental yang diajar dengan strategi demonstrasi dan memiliki efikasi diri rendah.

d. Rata-rata nilai hasil belajar mengolah makanan kontinental yang diajar dengan strategi latihan dan memiliki efikasi diri rendah tidak lebih baik dibandingkan dengan hasil belajar mengolah makanan kontinental yang diajar dengan strategi demonstrasi dan memiliki efikasi diri tinggi.

e. Rata-rata nilai hasil belajar mengolah makanan kontinental yang diajar dengan strategi demonstrasi dan memiliki efikasi diri rendah lebih baik dibandingkan dengan hasil belajar mengolah makanan kontinental yang diajar dengan strategi demonstrasi dan memiliki efikasi diri tinggi.

f. Rata-rata nilai hasil belajar mengolah makanan kontinental yang diajar dengan strategi demonstrasi dan memiliki efikasi diri rendah lebih baik dibandingkan dengan hasil belajar mengolah makanan kontinental yang diajar dengan strategi latihan dan memiliki efikasi diri rendah.

\section{Pembahasan}

Berdasarkan hasil-hasil perhitungan dalam penelitian yang diperoleh, terlihat bahwa hasil belajar mengolah makanan kontinental pada siswa yang diajar dengan strategi latihan adalah lebih tinggi jika dibandingkan dengan hasil belajar mengolah makanan kontinental yang diajar dengan strategi demonstrasi. Hal ini dimungkinkan karena dalam pembelajaran dengan menggunakan strategi latihan, siswa memiliki kesempatan untuk meningkatkan interaksi individual dengan setiap siswa yang lainnya dan serta kegiatan yang dilakukan dapat diulang-ulang seperti melatih keterampilan motoris, sehingga siswa terbiasa melakukan gerakan.

Pembentukan kebiasaan yang dilakukan dengan menggunakan strategi ini akan menambah ketepatan dan kecepatan pelaksanaan sehingga gerakan-gerakan yang kompleks dan rumit akan menjadi otomatis. Karena dalam strategi latihan pada saat proses berlangsungnya pembelajaran siswa betul-betul diberikan pengertian terlebih dahulu sebelum melaksanakan tugasnya yang diberikan guru. Hal ini sesuai dengan apa yang disebutkan Sabri (2010:60) tentang petunjuk bagaimana prinsip dan petunjuk menggunakan strategi latihan, yaitu: (1) siswa harus diberi pengertian yang mendalam sebelum diadakan latihan tertentu; (2) latihan untuk pertama kali hendaknya bersifat diagnosis, mula-mula kurang berhasil, lalu diadakan perbaikan untuk kemudian bisa lebih sempurna; (3) harus disesuaikan dengan taraf kemampuan siswa; dan (4) proses latihan hendaknya mendahulukan hal-hal yang esensial dan berguna.

Sementara dalam proses pembelajaran dengan strategi demonstrasi siswa lebih cenderung mengikuti perintah-perintah yang diberikan oleh guru sehingga siswa kurang kesempatan untuk mengembangkan kemampuan yang dimiliki. Dalam strategi pembelajaran demonstrasi, selama pertemuan berlangsung bahwa setiap perangkat keputusan dibuat oleh guru. Guru sebagai model untuk memperagakan hasil pembelajaran. Hal ini sesuai dengan apa yang dikemukakan Sanjaya (2007:150) strategi demonstrasi adalah strategi pembelajaran dengan memperagakan dan mempertunjukkan kepada siswa tentang suatu proses, situasi atau benda tertentu. Sedangkan pada tahap pasca pertemuan, guru memberikan umpan balik langsung kepada siswa, sasarannya harus memberikan banyak waktu pelaksanaan tugas.

Jadi pada dasarnya pembelajaran yang diberikan dengan strategi latihan diyakini 
keunggulannya dalam meningkatkan hasil belajar mengolah makanan kontimnental. Untuk siswa yang memperoleh pembelajaran dengan strategi latihan, merasakan adanya kebebasan dalam melakukan suatu gerakan dan mengulanginya tanpa ada suatu keterpaksaan dari guru untuk melakukannya. Dengan kata lain siswa yang diajar dengan strategi latihan ini tidak menyadari bahwa siswa diberikan kepercayaan untuk melakukan gerakan sesuai dengan kebutuhan dirinya dan siswa akan menemukan sendiri tingkat kesulitan-kesulitan yang nantinya akan ditemukan teknik-teknik pemecahannya.

Selain kenyataan yang dihadapi dalam penerapan strategi latihan tersebut, sejalan dengan temuan dalam penelitian ini telah menguatkan bahwa hasil belajar mengolah makanan kontinental yang diajar dengan strategi latihan lebih tinggi secara signifikan dari hasil pembelajaran yang diberikan dengan strategi demonstrasi.

Berdasarkan data yang diperoleh telah menunjukkan bahwa rata-rata hasil belajar mengolah makanan kontinental yang diajar dengan strategi latihan lebih tinggi daripada hasil belajar mengolah makanan kontinental yang diajar dengan strategi demonstrasi. Dari hasil perbandingan rata-rata yang diperoleh memberikan simpulan bahwa hasil perbandingan rata-rata hasil belajar mengolah makanan kontinental yang diajar dengan strategi latihan lebih tinggi dari hasil belajar mengolah makanan kontinental yang diajar dengan strategi demonstrasi. Hal ini sesuai dengan dugaan sebelumnya yang mengunggulkan strategi latihan dalam pembelajaran mengolah makanan kontinental. Keunggulan dari strategi latihan yang dipaparkan dalam kerangka berpikir terbukti secara empiris di lapangan, sehingga hasil ini telah menguatkan bahwa dengan strategi latihan hasil belajar mengolah makanan kontinental siswa lebih baik.

Siswa yang memiliki efikasi diri yang tinggi, maka dia akan lebih banyak membuat gerakan atau teknik-teknik yang bervariasi dalam mencapai tujuannya. Hal ini sesuai apa yang dikemukakan Luthans dan Stajkovic (2006:338), bahwa efikasi diri mengacu pada keyakinan individu (confidensi) mengenai kemampuannya untuk memobilisasi motivasi, sumber daya kognitif, dan tindakan yang diperlukan agar berhasil melaksanakan tugas dalam konteks tertentu. Selanjutnya Baron \&
Greenberg (1990), menyatakan efikasi diri adalah suatu kenyataan seseorang mengenai kemampuannya untuk melakukan tugas-tugas tertentu yang spesifik.

Efikasi diri dalam penelitian ini adalah gambaran yang dimiliki siswa mengenai dirinya sendiri yang terakumulasi dalam pandangan, perasaan, dan penilaiannya tentang kualitas dalam mengatasi kekhawatiran, kepanikan, dengan menunjukkan keberanian dan ketegasannya dalam mengambil keputusan untuk dirinya.

Efikasi diri akan mempengaruhi aktivitas yang ia lakukan karena apa yang akan dilakukan tergantung dari keyakinannya mampu atau tidak untuk melakukannya dan sebaliknya siswa yang memiliki efikasi diri rendah tidak suka melakukan aktivitasaktivitas yang berlebihan dan baru, karena tidak yakin dengan kemampuan dan penampilannya.

Hasil pengujian sesuai dengan pengujian hipotesis dan teori bahwa siswa yang memiliki efikasi diri tinggi mempunyai hasil belajar yang yang lebih tinggi daripada siswa yang mempunyai efikasi diri yang rendah. Hal ini diakibatkan karena siswa yang mempunyai efikasi diri tinggi memiliki keyakinan akan kemampuannya sehingga dia memiliki kemauan untuk belajar serta mempunyai motivasi tinggi untuk keberhasilannya. Sedangkan siswa yang memiliki efikasi diri rendah kurang memiliki rasa percaya diri akan kemampuannya mengakibatkan dia selalu terfokus pada perintah guru sehingga kemampuan belajarnya kurang berkembang, walaupun sebenarnya strategi mengajar demonstrasi cocok untuk siswa yang memiliki efikasi diri rendah. Sedangkan strategi latihan cocok untuk siswa yang mempunyai efikasi diri tinggi. Namunpun demikian diantara kedua strategi mengajar ini tetap strategi latihan yang lebih unggul karena dalam strategi latihan mengajak siswa untuk lebih berfikir kreatif dan dapat mengembangkan diri dibandingkan dengan strategi demonstrasi yang hanya bekerja dengan mengandalkan atas instruksi guru.

Siswa yang memiliki efikasi diri tinggi tidak cocok diberikan pembelajaran dengan strategi demonstrasi karena mereka kurang kreatif dan tidak dapat mengembangkan kemampuan yang dimilikinya. Sedangkan siswa yang memiliki efikasi diri rendah cocok menggunakan strategi demonstrasi karena 
dalam strategi demonstrasi segala aktivitas yang hendak dikerjakan siswa semuanya atas instruksi dan petunjuk dari guru, siswa hanya mengikutinya dan ini sesuai dengan efikasi diri rendah dimana siswanya kurang dapat mengembangkan sesuatu hal tanpa ada instruksi atau petunjuk dari guru karena menganggap dirinya tidak mampu berbuat sendiri.

\section{PENUTUP}

Pertama, hasil belajar mengolah makanan kontinental yang diajar dengan strategi latihan lebih tinggi dari pada hasil belajar mengolah makanan kontinental yang diajar dengan strategi demonstrasi.

Kedua, hasil belajar mengolah makanan kontinental yang memiliki efikasi diri tinggi lebih tinggi dari hasil belajar mengolah makanan kontinental yang memiliki efikasi diri rendah .

Ketiga, terdapat interaksi antara strategi mengajar dan efikasi diri terhadap

Hasil belajar mengolah makanan kontinental Kelas XI SMK Negeri 10 Medan. Dalam meningkatkan hasil belajar mengolah makanan kontinental, siswa yang memiliki efikasi diri tinggi lebih efektif di ajar dengan menggunakan strategi latihan, sedangkan siswa yang mempunyai efikasi diri rendah, lebih efektif diajar dengan menggunakan strategi demonstrasi.

\section{DAFTAR PUSTAKA}

Bandura, A. (1982). Self-Efficacy Mechanism in Human Agency. American Psychlogist. Vol.37.

Bryner, W. (1993). The Teacher Role, A Sosiological Analysis. British Manual of Sociology, NY: Appleton Century-Craft, Inc.
Dick, W. \& Carey, L. (2005). The systematic Design of Instructional. New York: Longman.

Dimyati \& Mujiono. (2006). Belajar dan Pembelajaran. Jakarta : Rineka Cipta

Gagne, R.M,. Brigs, L.J. (1979). Principles of Instructional Design, New York: Holt, Rinehart and Winston.

Gagne, R.M., Brigs, L.J. (1987). Instructional Technology Founations. Lawrence Erlbaum: New Jersey

Luthan, F., Stajkovic. (2006). Perilaku Organisasi, Yogyakarta: Andi.

Miarso, Y. (2007). Menyemaih Benih Teknologi Pendidikan, Jakarta: Kecana.

Romiszowsky, A.J. (1981). Designing Instructional System, New York: Nichol Publishing Company.

Sabri, A. (2010). Strategi Belajar Mengajar Micro Teaching. Ciputat. Quantum Teaching.

Sagala, S. (2007). Manajemen Strategik dalam Peningkatan Mutu Pendidikan. Bandung: Alfabeta.

Sagala, Syaiful. (2003). Konsep dan Makna Pembelajaran. Bandung: Alfabeta.

Seels, B.B. And Rita C. Richey. (1994). Instructional Technology, The Devitional and Domains of The Field, Washington DC: AECT

Silberman, M. (2009). Active Learning. Pustaka Insan Mandiri: Yogyakarta.

Sudjana. (1989). Metode Statistik. Bandung.: Tarsito

Sudjana. (2001). Metode dan Teknik Pembelajaran Partisipatif, Bandung: Falah Production.

Sudjana. (2005). Metode Statistika, Bandung: Tarsito.

Syah, Muhibbin. (2011). Psikologi Pendidikan dengan Pendekatan Baru, Bandung: Remaja Rosdakarya. 